Volume 7 Issue 2, June 2020

Nationally Accredited Journal,

Decree No. B/4130/E5/E5.2.1/2019

\title{
Ratio Decidendie Judges On The Cancellation Of Certificate Of Land Right That Does Not Remove The Ownership In Kendari State Court (Case Study On Decision No. 62 / Pdt.G / 2012 / PN.Kdi)
}

\begin{abstract}
Muh. Ramli Jaya ${ }^{1}$ And Akhmad Khisni ${ }^{2}$
Abstract. This study aims to determine how the Ratio Decidendie judges and legal consequences of the implementation of verdict on cancellation of certificate of ownership that does not remove the right to land ownership in the State Court of Kendari. This study uses the type of normative juridical research using law approach, conceptual approach and the approach the case with premier legal materials, secondary and tertiary material.

Based on the studies concluded that the judges verdict in case number 62 / Pdt.G / 2012 / Pn.Kdi confirming ownership of the Plaintiff. Certificate Revocation Proprietary No. 37 / Anduonuhu Village and property rights certificate No. 38 / Anduonuhu Village through Decision Kendari State Administrative Court No. 29 / G / 2010 / PTUN-Kdi flawed due to its publication of juridical / procedural defect. While consideration by the State Court case number 62 / Pdt.G / 2012 / Pn.Kdi explain pedestal of land rights in the form of Decree of the Governor of the Province of South East Celebes Number. 11 / HM / 1979 dated January 16, 1979 not been declared void. So that the Plaintiff's legal rights remain attached. Plaintiffs can reapply for the certificate issued by the applicable legislation.

Keywords: Ratio Decidendie; Certificate Revocation Property Rights; Land Rights.
\end{abstract}

\section{Introduction}

Land has an economic value, an element that could not be ruled out in the era of national development and to support economic growth. Besides the economic value, the land also has a social value, which means the land rights are not absolute, but the state guarantee and respect the land rights granted to citizens, so it is necessary legal certainty in land tenure is protected by the Act. The setting of civil law regarding the object / wealth has poured in some laws, such as Act No. 5 of 1960 on Agrarian (BAL), Act No. 37 of 2004 on Bankruptcy, etc. ${ }^{3}$

Soil is the object of the most susceptible to the dispute, whether the dispute between individuals, disputes the individual with legal entities, disputes between legal entities, even disputes involving government, thus setting the relevant legal tenure / land titling should be maximized to ensure the protection of the rights holder on the ground, so the importance of land uses for the person or legal entity requires the guarantee of legal certainty on the land.

The provisions on legal certainty of the land rights stipulated in Government Regulation No. 10 of 1961 on Land Registration. Then according to the dynamics of its development, is enhanced with Government Regulation Government Regulation No. 24 of 1997 on Land Registration.

\footnotetext{
${ }^{1}$ Student Master of Notary Program (Mkn) Sultan Agung Islamic University, Semarang, Email: ramli law@yahoo.co.id

${ }^{2}$ Lecturer, Faculty of Law, Sultan Agung Islamic University, Semarang

${ }^{3}$ Soetami Siti, 2008, Pengantar Tata Hukum Indonesia, Bandung: PT. Refika Aditama, p. 10
} 
Article 1, paragraph 20 PP 24 in 1997 that "The certificate is proof of the rights referred to in Article 19 paragraph (2) c BAL for land rights, property rights, land endowments, ownership of the apartment units and the right in each of which has been recorded in land book".

A certificate is a proof that the ownership of a plot of land someone has registered, a certificate as proof of rights are not a guarantee of protection of a person's legal certainty on land already owned.

As One case of disputes over land ownership rights that have been certified property rights on parcels of land occurred in Kendari in 2011. Based on the Decision Kendari State Administrative Court No. 29 / G / 2010 / PTUN-Kdi decided that declaring void the Decree of Administration state Property rights in the form of Certificate No. 37 / Anduonuhu Village and property rights certificate No. 38 / Anduonuhu Village on behalf Tindak Djioen for SHM has been flawed juridical so it should also be declared void.

Subsequently in 2012 The owner of the canceled SHM filed a lawsuit related to ownership disputes in Civil State Court Kendari case registration Number 062 /Pdt.G/2012/Pn.Kdi. on the lawsuit judges verdict confirming the ownership of the Plaintiff (the expert inheritance of Alm. Tindak Djioen as Plaintiff), claiming that the disputed land area of $15,800 \mathrm{~m} 2$ of land is owned by the Plaintiff which is a unit of land area of 40,000 M2 Plaintiff;

Thus the emergence of civil disputes between the parties, in order to prove the legal guarantee of the land settled by the courts.

Based on the above writer lift the title "Ratio Decidendie Judges On The Cancellation Of Certificate Of Land Right That Does Not Remove The Ownership In Kendari State Court (Case Study On Decision No. 62 / Pdt.G / 2012 / PN.Kdi)".

Based on the things that have been described in the background of the problem, it is necessary to put forward the formulation of the problem 1) What are the Ratio Decidendie Judges in Decision No. 62 / Pdt.G / 2012 / Pn.kdi in the State Court of Kendari 2) What legal consequences on Implementation of the Decision of Judge No. 62 / Pdt.G / 2012 / Pn. Kdi

\section{Research Methods}

In this study, the authors used normative juridical approach by studying books, legislation, journals and other documents has become that in analyzing the problem formulation with this research through legislation Approach, Conceptual Approach and Case Approach. Legislation approach (statue approach) associated with the problem, namely About Act No. 5 of 1960 on Basic Regulation of Agrarian, the Book of the Law of Civil Law, Government Regulation No.24 of 1997 on Government Regulation Number 10 of 1961 on Land Registration. Conceptual Approach were moved from the doctrines developed in the jurisprudence that will find the ideas that gave birth to the concept of law. And legal principles relevant to the research problems studied. ${ }^{4}$ Case Approach that need to be considered by the researchers is Ratio Decidendie, legal grounds used by the judges to arrive at its decision.

Specifications of this study is to determine the legal study of law, principles of law, as well as the legal doctrines in order to address the legal issues at hand. ${ }^{5}$ Types and Sources of materials used in this study, there are three kinds: 1) Primary material, composed of laws and regulations relating to the issues studied, About Act No. 5 of 1960 on Basic Regulation of Agrarian. The principal Act of Civil Law, Government

${ }^{4}$ Ibid p. 97

${ }^{5}$ Peter Mahmud Marsuki, 2008, Penelitian Hukum, Jakarta: Kencana, p. 35 
Volume 7 Issue 2, June 2020

Nationally Accredited Journal,

Decree No. B/4130/E5/E5.2.1/2019

Regulation No.24 of 1997 on Government Regulation No.10 of 1961 on Land Registration, Act No. 48 of 2009 on the powers of Justice, Decision No. 62 / Pdt.G / 2012 / PN.KDI and jurisprudence , 2) Secondary material, in the form of literature studies legal materials, which includes books, dissertation, journals, theses legal dictionaries and other scientific articles. 3) tertiary material, in the form of legal clarification primary and secondary material related to the research include, legal dictionary, large Indonesian dictionary.

The data collected in this study is a technique obtain legal materials by means of the literature research (Library Research). Such research regarding commonly also called "Legal Research" which collects materials from references that support to this study (a study of literature in the form of documents, literatures, the articles dealing with the problem).

Data analysis method used in this research is qualitative analysis method. From a study of documents and literature and then analyzed what the basis that the property not be delete / disappear after certificate canceled property rights in the decision that which is supported by a wide range of constituent data obtained either from primary legal materials, secondary and tertiary.

\section{Results And Discussion}

In connection with the certificate as proof of rights is strong, a certificate issued by the District Land Office / cities are still inviolable by other parties who feel aggrieved over the issuance of the certificate. It was brought to court of the country if a civil dispute, whereas a lawsuit filed to the Administrative Court if the state efforts of state administrative disputes. The lawsuit stated that the certificate is invalid or void. ${ }^{6}$

On 11 August 2010, Mr. Kadir Sandewa, filed at the Court order the Kendari State Court with case number 29 / G / 2010 / PTUN-KDI to the Head Office of the Land nationwide Southeast Celebes Province as Defendant I, Head of the Land Office Kendari as Defendant II related to the cancellation of property right certificate No. 37 in 1980 and the certificate No. 38 In 1980, on behalf of the Tindak Djioen and then Dadang Paradanata, Dade Prat Untarti, Jaji Pradza Kathrien Meads and Bernhardy Ralda file an application Intervention as heirs (deceased) Tindak Djioen by a certificate of inheritance, as the holders of such certificates submitted his application to be canceled through a lawsuit.

In explaining the Petitioner's argument that the disputed land was originally occupied by the brother then in 1974 transferred in corresponding Certificate of indemnity dated October 20, 1974 No. 12 / AGR / Village / 1974 then the heirs submit to the appropriate Sandewa Kadir brother heir affidavit dated January 6, 2010 No.04 / KA / I / 2010. Then Kadir Sandewa apply for the issuance of the certificate at the land office Kendari, but after the measured and processed the results of measurement to be plotted on a map of the parent, it is known that on the land has risen Certificate of right number 37 / Anduonohu Village top name acts Djioen, dated January 28, 1980, drawing situation number 101/1980 dated January 24, 1980 of 20.

The canon of the Defendants and the Applicant Intervention explained that the object of the dispute land originally derived from land rights by the State filed Tindak Djioen, then measuring, installation of boundary markers as set forth in FIG situation dated January 24, 1980 No. 101 / GS / 1980 of 20,000 M2 and picture the situation on 24

\footnotetext{
${ }^{6}$ Urip Santoso, 2017, Perolehan hak atas tanah, Depok: Kencana, p. 169
} 
January No. 102 / GS / 1980 of 20,000 M2 after study physical data and juridical administration turns proprietary petition meets the requirements, then issued Decree Governor Head TK I Southeast Celebes January 16, 1979 No. 11 / HM / 1979. On the basis of physical data and juridical meet administrative requirements then issued a right certificate No. 37 / Anduonohu Village and right of ownership No. 38 / Village Anduonohu under named Tindak Djioen.

The lawsuit against the judge has said and decided cancellation of the Certificate Properties no. 37 / Anduonohu Village and Property Rights Certificate no. 38 / Village Anduonohu Tindak Djioen. In order to implement court decisions that have permanent legal force then on December 8, 2014, Head of the Regional Office of the National Land Agency Southeast Celebes Provincial Government issued Decree No. 01 / PBT / BPN-74/2014 About Right Cancellation number 37 / Anduonohu On behalf of Tindak Djioen of 20,000 M2 and Proprietary number 38 / Anduonohu On behalf of Tindak Djioen of $20,000 \mathrm{M} 2$.

\subsection{Ratio Decidendie in Decision No. 62 / Pdt.G / 2012 / Pn.kdi in the State Court of Kendari}

That the cancellation was related errors appropriate administrative procedures Procedure as consideration of the judge in the verdict factie Judex law in its decision on page 33 paragraph $2 .^{7}$

"Considers that the arguments of Plaintiff, Defendant I Party has submitted a response dated October 18, 2010 which essentially states that the object of dispute publication quo there is no synchronization between the Decree of the Governor Head of First Level No. 11 / HM / 1979 January 16 on behalf of Umar K. et al (44 people) with a certificate issued by the regent KDH Tk II Kendari Ub Head of Sub Directorate of land registration (according to the Land Office on the ground guide Kendari) that process is not in accordance with the land administration as well as to Government Regulation No. 10 of 1961 on Land Registration, DI No. 51973 on provisions concerning the procedures for the granting of Land and DI No. 61972 On Granting Delegation of authority over land ".

Furthermore, on July 19 Paradanata, Dade Prat Untarti, Jaji Pradza Kathrien Meads and Bernhardy Ralda as heirs (deceased) Tindak Djioen filed a suit against Kadir Sandewa Kendari State Court with case registration number 62 / Pdt.G / 2012 / P.KDI. On tort lawsuit, Judge has decided Judge give judgment as follows: ${ }^{8}$

Considering that based on the evidence $\mathrm{T}-2$ stated that the reason for the cancellation of the Certificate of Property Rights on behalf Tindak Djioen is due to occur discrepancy of data in minutes edaphology Decree on behalf of the Governor KDH Tk 1 Southeast Celebes by the Chief Directorate of Agrarian Tk 1 with two SHM in the name Tindak Djioen regarding the date and the number of images of the situation, which in the case of SHM on behalf of Tindak Djioen listed on 24 January 1980 with the number 102 , while the minutes of the examination and the Decree of the governor No. 11 / HM / 1979 which is a prerequisite Legal publication of both SHM is listed 20th June 1977 under No. 120, so that the second publication of SHM has a defect procedural / formal; Considering, that based on the considerations described above, the restriction Certificate ownership No. 37 / Village Anduonohu and Certificate Properties No. 38 / Village Anduonohu respectively on behalf of the Tindak Djioen does not necessarily

\footnotetext{
7 Decision Kendari State Administrative Court No. 29 / G / 2010 / PTUN-Kdi dated January 26, 2011

${ }^{8}$ Decision No. 62 / Pdt.G / 2012 / Pn.Kdi, dated 31 July 2013 case 31- 33
} 
Volume 7 Issue 2, June 2020

Nationally Accredited Journal,

Decree No. B/4130/E5/E5.2.1/2019

eliminate / eliminate the Property Rights of land on behalf of the Tindak Djioen as contained in the Letter decision of the Provincial Governor 1 Southeast Celebes No. 11 / HM / 1979 dated January 16, 1979 due to the cancellation of the certificate is due to negligence on the part of the National Land Agency Southeast Celebes Province is wrong in stating the date and number picture the situation in the certificate resulting in a discrepancy of data treatise edaphology and cancellation of the certificate is not caused by it unlawful issuance of Decree Provincial Governor 1 Southeast Celebes Number:11 / HM / 1979 dated January 16, 1979 which is a pedestal right to obtain a certificate of ownership of the land, so to land on behalf of the Tindak Djioen can still be filed reapply for the certificate issued;

Considering that, in accordance with the location and boundaries of the disputed land above, the disputed land is included in part of the land belonging to Tindak Djioen as to which depends on Decree Provincial Governor 1 Southeast Celebes No. 11 / HM / 1979 dated January 16, 1979;

From the consideration of the judge has explained that the board right over the disputed land ownership certificate No. 37 and 38 in 1980 has never been declared void, and therefore never declared void then legally the property of the heirs of the deceased. Tindak Djioen remain attached even if the certificate has been declared void, since the issuance of evidence of rights in the form of SHM No. 37 and 38 are wrong in publishing / procedural defects that were canceled but the heirs of the deceased. Tindak Djioen can file a return to the land of Kendari's Office issued proof of new rights because such rights pedestal Decree Provincial Governor 1 Southeast Celebes No. 11 / HM / 1979 dated January 16, 1979, have not been declared void.

See the ruling of Justice in Case among heirs Tindak Djioen and Kadir Declatoir Sandewa is the kind of decision that one verdict Stating that the disputed land area of $15,800 \mathrm{M}^{2}$ located in Anduonohu district. Kendari is the Plaintiff which is a unit of land area of $40,000 \mathrm{M}^{2}$ plaintiff.

\subsection{Implementation of the Legal Consequences of Judges Decision No. 62 / Pdt.G / 2012 / Pn. Kdi}

Civil cases that the legal process in the State Court of Kendari between Kadir Sandewa against Heirs of Tindak Djioen now been legally binding court decision as Kendari no. 62 / Pdt.G / 2012 / PN.kdi July 31, 2013 Jo. Southeast Celebes High Court Decision No. 23 / Pdt / 2014 / PT. Southeast Celebes May 122014 Jo. Decision Mari No. 131 K / Pdt / 2015 dated May 13, 2015;

The consideration of judges On page 27, paragraph 3 in the decision of the Supreme Court No. $131 \mathrm{~K} /$ pdt / 2015 dated May 13, 2015, which reads "that the cancellation of both SHM due to" negligence "BPN is one of Identification Number and date picture of the situation (GS) does not cause the rights of Ownership Tindak Djioen fall, because according to the rules of the heirs ic the Plaintiff may file an application to BPN for the issuance of new SHM adjusted with dates and numbers "image GS" correct "

Because of the improper procedure / an oversight body the National Land in mentioning the number and date of the picture of the situation, then the heir Alm. Colonel Czi. (Ret) Tindak Djioen has been confirmed proprietary rights over land disputed by civil verdict in the State Court of Kendari legally can apply for the issuance of a new certificate at the Land Office of Kendari

Decision of the Supreme Court Reg No. 335 K / TUN / 2011 dated 28 November 2011 Jo. Decision of the State Administrative High Court Makassar No. 33 / B.TUN / 2011 / 
PT. TUN.Mks, dated June 14, 2011 Jo. Decision Kendari State Administrative Court No. 29 / G / 2010 / Pn. Kdi dated 26 January 2011, does not eliminate / eliminate the right of ownership of the land on behalf of Tindak Djioen as stated in the Decree of the Governor of the Province of South East Celebes No. 11 / HM / 1979 dated January 16, 1979 (PROOF P-5), and as well a letter from the National land Agency Regional Office of Southeast Celebes Province No. 050 / 19-74 / I / 2016 dated January 22, 2016, the heirs of the deceased.

\section{Clossing}

Based on the overview of the position of the case, legal issues, summary judgment and consideration of the judges panel of judges, as well as the analysis described, it can be concluded as follows:

- Ratio Decidendie Judges of the case property ownership disputes between experts the inheritance of Alm. Tindak Djioen with Kadir Sandewa in Kendari State Court No. /Pdt.G/2012/Pn.Kdi 062 dated July 31, 2013, the certificates had been declared void by decree Kendari State Administrative Decision No. Kendari State Administrative Court No. 29 / G / 2010 / PTUN-Kdi dated 26 January 2011 as flawed administration is an act of erasure proof of ownership rights in the form of a certificate, but not necessarily civil rights of a person is gone as well, because legally the right base of land ownership is never declared void, due to the cancellation of land rights are classified as defective administration that procedural errors, misapplication of the legislation, errors subject of rights, the rights object error, right type of error, miscalculation spacious, there overlapping land rights, juridical or physical data is not correct, or other errors of administrative legal nature. Therefore, the right ownership is still attached to the Heirs Alm. Tindak Djioen

- The legal consequences of the decision of the State Court of Kendari No. /Pdt.G/2012/Pn.Kdi 062 dated 31 July 2013. Ownership rights are still attached to the heirs of the late Tindak Djioen and the right base in the form of Decree of the Governor of the Province of South East Celebes Number. 11 / HM / 1979 dated January 16, 1979 was never declared void, so as to land on behalf of the Tindak Djioen may be filed Reapply to the certificate issued by the legislation in force.

\section{References}

[1] Peter Mahmud Marsuki, 2008, Penelitian Hukum, Jakarta: Kencana

[2] Urip Santoso, 2017, Perolehan Hak Atas tanah, Depok: Kencana

[3] Siti Soetami 2008, Pengantar Tata Hukum Indonesia, Bandung: PT. Refika Aditama

[4] Decision Kendari State Administrative Court No. 29 / G / 2010 / PTUN-Kdi dated January 26, 2011

[5] Decision No. 62 / Pdt.G / 2012 / Pn.Kdi, dated 31 July 2013 